\title{
The Advantages of Using Mesenchymal Stem Cells in the Treatment of Massive Burns-Case Report
}

\section{Oproiu $\mathrm{AM}^{1,2 *}$ and Grigore $\mathrm{A}^{2}$}

${ }^{1}$ Department of Plastic Surgery, University of Medicine and Pharmacy, Romania

${ }^{2}$ Emergency University Hospital of Bucharest, Romania

*Corresponding author: Ana Maria Oproiu, Department of Plastic Surgery,

\section{Research Article \\ Volume 3 Issue 2}

Received Date: November 18, 2019

Published Date: December 30, 2019

DOI: $10.23880 /$ jes- 16000132 University Emergency Hospital, Bucharest, Romania, Email: anamariaoproiu@gmail.com

\section{Abstract}

Due to insufficient oxygenation of tissues, cellular and vascular destruction, burns show a different healing process from other wounds. Even if it affects only one organ, namely the skin, it can generate a systematic response in which multiple organs are affected, with high risk of infections and mortality.

Therefore it represents a challenging pathology with the involvement of several specialties, which, depending on the way of production, the surface and the depth of the burn, requires special care, long hospitalizations, and multiple surgical interventions. Even if with the evolution of the medicine, the mortality of burns was also improved, the healing process is often unsatisfactory with negative consequences on the functional and physical aspects, which reduce the quality of the patient's life.

This work paper aims to present a different approach in the management of a II-III degree burn, of approximately $20 \%$ body surface, at the level of the posterior thorax and the left upper extremity, using mesenchymal stem cells. The procedure involved the collection of skin samples with a diameter of $5 \mathrm{~mm}$ each one, match them with saline solution, introduce them in a special device, disaggregate them and inject the resulting suspension solution rich in mesenchymal stem cells into the dermis with the advantage that it can skip over the excisional debridement stage and decrease significantly large skin graft donor areas of the standard approach, and other possible surgical interventions subsequent.

Keywords: Burns; Wounds; Skin; Healing Process; Mesenchymal Stem Cells

\section{Introduction}

In USA, approximately 1, 2 million new cases are reported annually, of which 40,000 require hospitalization and 5000 die because of complications, most of them due to sepsis, infections or inhalation [1-7].
In order to properly manage the burn cases, it is important to evaluate the burn injury correctly and to know the healing process which is different from the other wounds (Table 1).

Even if the phases are the same in every wound, the duration of each step is different in burns [8-10]. 


\section{Journal of Embryology \& Stem Cell Research}

\begin{tabular}{|c|c|}
\hline \multirow{8}{*}{$\begin{array}{l}\text { Inflammatory } \\
\text { phase }\end{array}$} & 1. vascular response \\
\hline & vasodilation \\
\hline & extravasation of fluid \\
\hline & $\begin{array}{l}\text { massive burns require fluid replacement because of massive extravasation of plasma due to } \\
\text { increased capillary permeability }\end{array}$ \\
\hline & 2. cellular response \\
\hline & migration of the neutrophils and monocytes at the site of inflammation \\
\hline & later, macrophages replaced the neutrophils \\
\hline & role in the phagocytosis and cleaning of death tissue and toxins released by the burn injury \\
\hline \multirow{2}{*}{ Proliferative phase } & starts few hours after injury and covers the wound within 5-7 days in partial thickness \\
\hline & is delayed in deep burns \\
\hline \multirow{2}{*}{ Remodeling phase } & the extracellular matrix produce the scar formation \\
\hline & the process could take years in the deep burn \\
\hline
\end{tabular}

Table 1: Burn healing process.

If in the no burn wounds the tissue is fed by underlying blood supplies, the burn injury is characterized by a zone of coagulate necrosis, where the tissue is not sufficiently oxygenated to response to normal healing process. Surrounding this necrosis is a zone of stasis in which is decreased the perfusion of the tissues. Also high capillary permeability, local inflammatory reaction, vasodilation and edema distinguish burns from other trauma injury [11-13].
An important part of diagnosis is represented by identifying the causative agents (physical, thermal, electrical, radiation, laser, chemical burns) and the depth of burns (Table 2) because local and systematic management is different according to the way of production, the surface and the depth of the burns [14$16]$.

\begin{tabular}{|l|l|}
\hline \multirow{3}{*}{$\begin{array}{c}\text { First Degree Burn } \\
\text { (epithelial burns) }\end{array}$} & Skin is erytematic without vesication \\
\cline { 2 - 3 } & -very painful to the touch \\
\hline \multirow{5}{*}{ Second-Degree Burns } & -buPk capillary refill \\
\hline & - only papillary dermis is involved \\
\cline { 2 - 2 } & - very painful to the touch \\
\cline { 2 - 2 } & - brisk capillary refill \\
\cline { 2 - 2 } & DEEP- eschar formation \\
\cline { 2 - 2 } & -deep reticular dermis is involved \\
\hline \multirow{4}{*}{ Third-Degree Deep } & Full thickness \\
\cline { 2 - 2 } & Presence of eschar \\
\cline { 2 - 2 } & $\begin{array}{l}\text { Markers: pain(high to none), color( pink/red to white/brown), capillary refill(brisk } \\
\text { to none) }\end{array}$ \\
\hline
\end{tabular}

Table 2: First Degree Burn.

Severe burns, representing by over $20 \%$ total body surface area, are characterized by a systematic inflammatory response with the damage of immune system, gastrointestinal system, muscle and hyper metabolism [17]. They require specialized burn centers, special nutrition, control of pain, infection prevention, and rehabilitation is an important part of this process.

If in the first and second superficial degree burns, the healing is by primary intention, in the deep burns the healing is by secondary intention and requires surgical treatments, often multiple surgical interventions, with risk of contraction, hypertrophic scar, late deformities, delaying the patient return to normal.

Regenerative medicine represents a promising approach in the wound healing, but to be able to apply is very important to understand the healing process.

Recent, the medicine paid attention on stem cell because of their capacity to restore damaged tissue. Mesenchymal stem cells are known for their property to 


\section{Journal of Embryology \& Stem Cell Research}

be used as autologous, be transplanted for reparing and regeneration the tissue in the clinical practice. It is known that the dermis and the adipose tissue are sources of stem cells [18-20].

Adipose stem cells have proven to be a superior source of stem cells, even than bone marrow, because of higher quantities and numbers, protective and/or supportive factors which play a role in reducing apoptosis, fibrosis, and inflammation, and also because of the production of a larger number of growth factors [21].

\section{Materials and Methods}

We present a case report of a 51 old male with severe burns, $20 \%$ body surface through flammable liquid, grade II-III, which involved left upper extremity and posterior thorax (Figure 1), from whom we applied a different approach from the standard. With the help of an innovative technology called Rigenera, we obtained dermal micro grafts after the tissue was disaggregated by mechanical movements, rich in mesenchymal stem cells.

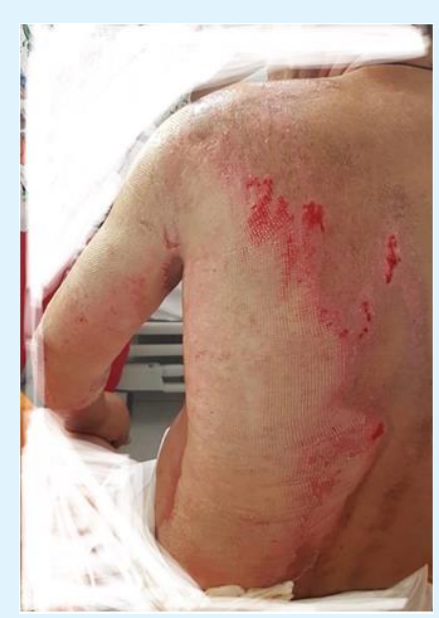

Figure 1: Seven days after burn injury, applying a "wait and see" approach.

The technique consists in harvesting the skin using a biopsy punch, introducing it into a special device and disaggregates it by mechanical movements, the result being a micro graft product rich in mesenchymal stem cells, which is injected in the lesion.

The steps we followed consisted in

- Choice of donor site inner anterior right thigh.

Oproiu AM and Grigore A. The Advantages of Using Mesenchymal Stem Cells in the Treatment of Massive Burns-Case Report. J Embryol Stem Cell Res 2019, 3(2): 000132.
- Shaving the donor site gently to remove the epidermis until it starts a superficial bleeding.

- Harvest the tissue with a $5 \mathrm{~mm}$ punch biopsy according to the size of lesion, considering that $1 \mathrm{~mm}^{2}$ of the collected tissue was expected to regenerate $2 \mathrm{~cm}$ of injury (Figure 2).

- Introduce the samples in the special device (2 samples/ session) and add $3 \mathrm{ml}$ of saline solution.

- Connecting the device to the machine and letting work for 2 minutes to provide a mechanical disaggregation into a suspension which contains autologous dermal micro graft.

- Introduce the suspension in a sterile syringe.

- Inject the solution in the burn lesion, at a depth of $4 \mathrm{~mm}$ (Figure 3).

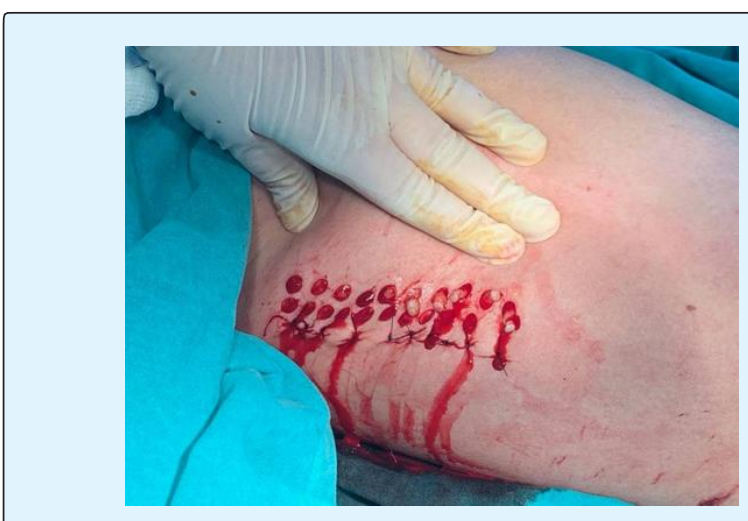

Figure 2: Tissue samples before the disaggregation; the skin sample contains both dermis and adipose tissue, known to be source of mesenchymal stem cells.

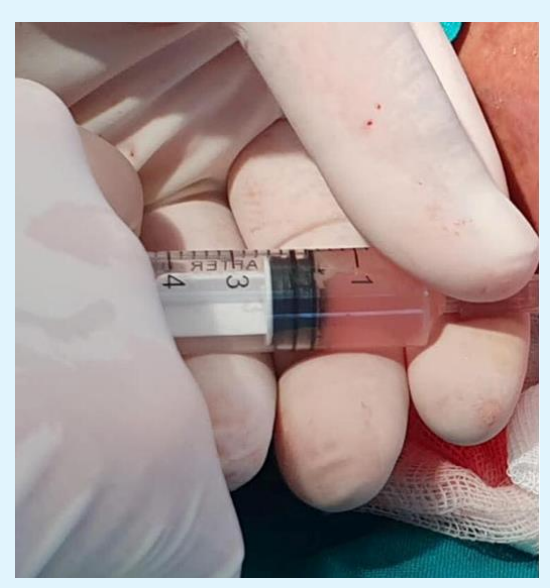

Figure 3: The suspension riches in mesenchymal stem cells are injected into the dermis. 


\section{Journal of Embryology \& Stem Cell Research}

\section{Results}

Clinical observation has documented diminished healing process with good aesthetic results, a better control of pain, without complications and a decreased in hospitalization days up to $50 \%$.

The immediately postoperatively result was impressive. The eschar zone coloured from white to red, was bleeding and marked by streches of mesenchymal stem cell suspension, (Figure 4) being an important tool in the prevent of the power of this suspension.

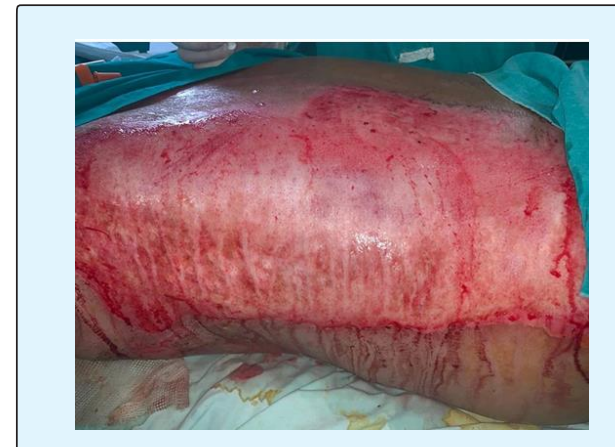

Figure 4: Immediately postoperatively.
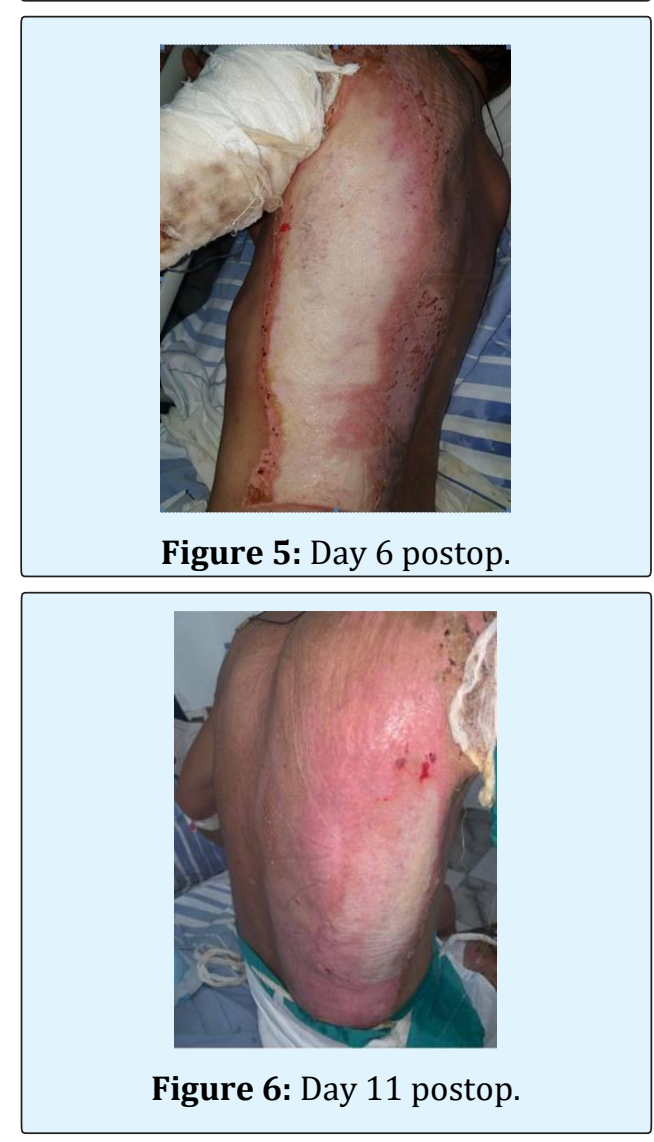

Oproiu AM and Grigore A. The Advantages of Using Mesenchymal Stem Cells in the Treatment of Massive Burns-Case Report. J Embryol Stem Cell Res 2019, 3(2): 000132.
Also, we noticed that the healing had begun from the periphery of the lesion (Figures 5\&6).

The skin is the largest organ of the body with the role of barrier, thermoregulation, avoidance of liquid loss, sensitive, production of vitamin D and any injury disrupts these functions. Using the Rigenera technology, we have been able to isolate mesenchymal stem cells and also a suspension riched in progenitor cells and growth factors easy to apply at the level of injury, which had the effect to accelerate the healing process, avoiding a contracting scar and restoring all the functions of the skin.

Studies showed that dermal micro grafts collected by Rigenera device present mesenchymal stem cell markers such as CD 73, CD 90, CD 105, and CD 34 [22]. Also, it had been demonstrated that approximately $70-80 \%$ of the isolated cells are mesenchymal stem cells [23].

During hospitalization, the patient had hyperproteic and hypercaloric diet, and usual scheme of anti biotherapy to avoid infections and didn't have any complication.

To compare the time and the way of healing between standard method (requires excisional debridement and skin graft) versus Rigenera technique, we chose the standard procedure at the upper extremity and in the third upper arm we also injected the suspension with progenitor cells (Figure 7).

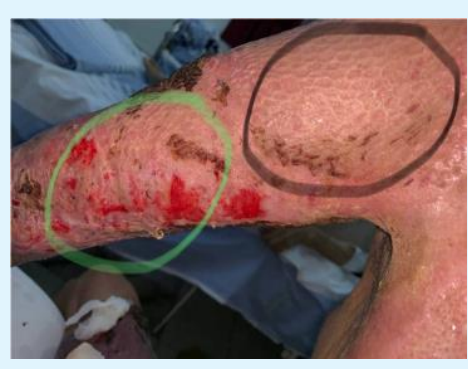

Figure 7: Fourteen days postop after skin grafting. In the third upper arm we also injected mesenchymal stem cell suspension. It is obvious that the healing process was accelerated using mesenchymal stem cell suspension.

The standard method starts with the excision of necrotic tissue but it has the following disadvantages:

- It requires also healthy tissue excision, the excision should be done until the tissue is bleending,

- It needs large donor sites, 


\section{Journal of Embryology \& Stem Cell Research}

- The risk that the skin graft do not adhere,

- Risk of progressive tissue damage due to unexcused partal-thickness burns and the zone of stasis in excised full-thickness burns.

So, usually, a "wait and see" approach is better to avoid health tissue removal but the risk or infections is increased.

In order to avoid large skin donor areas, rhis technique allowed to collect 30 samples of skin with the diameter of $5 \mathrm{~mm}$ each one for cover the posterior thorax and $1 / 3$ upper arm. For the rest of the upper extremity, we decided to practice the excision of necrotic tissue and skin graft, because of a more accurate evaluation of those methods. We observed that with the help of micro grafts, the healing process is accelerated and the risk of skin graft to not adhere doesn't exist.

Another aspect that we managed very well was the dressing. The burn patients require special daily dressing change under sedation due to high pain. The protocol of mesenchymal stem cells requires that the dressings to be changed at the 3 days, not daily, and it wasn't necessary the sedation. The pain was controlled very well. A big problem of the burns is the pain. The pain is very hard to control, even with a special scheme of pain relievers.

Even if the immunomodulatory function of the mesenchymal stem cells is uncleared, studies promote tissue repair, because of the production of the multiple growth factors, cytokines, collagens and matrix metalloproteinase, promote migrations of keratinocytes and also the differentiation and angiogenesis. The advantage of mesenchymal stem cells is that it can be isolated from a variety of tissue, including not only amniotic membrane, umbilical cord, cord blood, but also bone marrow, adipose tissue, hair follicle dermal papilla and sheath and they enhance process of healing, takeing part in all the phases of healing.

\section{Conclusions}

Massive burns represent a different injury which requires many resources, both from the patient and from medical staff and hospital too, with a delayed healing process.

The mesenchymal stem cells represent a promising approach in the wound healing and in the regenerative medicine, with an imunomodulatory function

Oproiu AM and Grigore A. The Advantages of Using Mesenchymal Stem Cells in the Treatment of Massive Burns-Case Report. J Embryol Stem Cell Res 2019, 3(2): 000132. uncompletely elicited, but with many possible clinical applications.

Regarding burns, adipose stem cells are a very accessible source of mesenchymal stem cells, which have demonstrated their role in accelerating the process of healing and minimalizing the complications.

\section{Conflict of Interests}

The authors didn't have any conflict of interests and they had equal contributions.

\section{Bibliography}

1. Thorne CH, Bartlett SP, Beasley RW, Aston SJ, Gurtner GC, et al. (2006) Wolters Kluwer Health/Lippincott William \& Wilkins.

2. (2014) Burn Incidence and Treatment in the US 2016. Burn Incidence Fact Sheet.

3. (2002) United States fire/burn deaths and rates per 100,000, in National Center for Injury Prevention and Control. Centers for Disease Control and Prevention.

4. (1993) Fire in the United States, 1983 to 1990. Emmitsburg MD: National Fire Data Center.

5. Roth JJ, Hughes WB (2004) The Essential Burn Unit Handbook. St. Louis. MO: Quality Medical Publishing pp: 141.

6. Atiyeh BS, Ioannovich J, Magliacani G, Masellis M, Costagliola M, et al. (2002) Efficacy of moist exposed burn ointment in the management of cutaneous wounds and ulcers: a multicenter pilot study. Ann Plast Surg 48(2): 226-227.

7. Baker CC, Miller CL, Trunkey DD (1979) Predicting fatal sepsis in burn patients. J Trauma 19(9): 641648.

8. Werner S, Grose R (2003) Regulation of wound healing by growth factors and cytokines. Physiol Rev 83(3): 835-870.

9. Kumar V, Abbas AK, Fausto N, Aster JC (2009) Tissue renewal, repair and regeneration. In: Kumar V, Abbas AK, Fausto N, Aster JC, et al. Robbins and Cotran $8^{\text {th }}$ (Edn.), Pensylvannia: Saunders pp: 191-216.

10. Sephel GC, Woodward SC (2001) Repair, regeneration and fibrosis. In: Rubin E, Gorstein F, Rubin R, 


\section{Journal of Embryology \& Stem Cell Research}

Schwarting R, Strayer D, et al. (Eds.), Rubin's pathology. Clinico pathologic foundations of medicine. $4^{\text {th }}$ (Edn.), Philadephia: Lippincott Williams and Wilkins pp: 85-116.

11. Gibran NS, Heimbach DM (2000) Current status of burn wound pathophysiology. Clin Plast Surg 27(1): $11-22$.

12. Vo LT, Papworth GD, Delaney PM, Barkla DH, King RG (1998) A study of vascular response to thermal injury on hairless mice by fibre optic confocal imaging, laser doppler flowmetry and conventional histology. Burns 24(4): 319-324.

13. Tiwari VK (2012) Burn wound: how it differs from other wounds?. Indian J Plast Surg 45(2): 364-373.

14. Deodhar AK, Rana RE (1997) Surgical physiology of wound healing: A review. J Postgrad Med 43(2): 5256.

15. Ethridge RT, Leong M, Phillips L (2009) Wound healing. In: Touensend CM, Beauchamp RD, Evers BM, Mattox KL, et al. (Eds.), Sabiston Textbook of surgery. $18^{\text {th }}$ (Edn.), Philadephia: Saunders pp: 191-216.

16. Bhattacharya $S$ (2009) Etiology and classification. In: Sarabahi S, Tiwari VK, Goel A, et al. (Eds.), Principles and practice of burn care pp: 25-36.

17. Stone Ii R, Natesan S, Kowalczewski CJ, Mangum LH, Clay NE, et al. (2018) Advancements in Regenerative Strategies Through the Continuum of Burn Care. Front Pharmacol 9: 672.
18. Chua AW, Khoo YC, Tan BK, Tan KC, Foo CL, et al. (2016) Skin tissue engineering advances in severe burns: review and therapeutic applications. Burns Trauma 4: 3 .

19. Wu Y, Chen L, Scott PG, Tredget EE (2007) Mesenchymal stem cells enhance wound healing through differentiation and angiogenesis. Stem Cells 25(10): 2648-2659.

20. Mansilla E, Aquino VD, Roque G, Tau JM, Maceira A (2012) Time and regeneration in burns treatment: heading into the first worldwide clinical trial with cadaveric mesenchymal stem cells. Burns 38(3): 450452.

21. Kocan B, Maziarz A, Tabarkiewicz J, Ochiya T, Banaś Ząbczyk A (2017) Trophic Activity and Phenotype of Adipose Tissue-Derived Mesenchymal Stem Cells as a Background of Their Regenerative Potential. Stem Cells Int 2017: 1653254.

22. De Fracancesco, Graziano A, Trovato L, Ceccarelli G, Romano M, et al. (2016) A regenerative approach with dermal micrografts in the treatment of chronic ulcers. Stem Cell Rev Rep 13(1): 139-148.

23. Svolacchia F, Francesco FD, Trovato L, Graziano A, Ferraro GA (2016) An innovative regenerative treatment of scars with dermal micrografts. J Cosmet Dermatol 15(3): 245-253. 